\title{
A new Ophiostoma species from loblolly pine roots in the southeastern United States
}

\author{
James W. Zanzot ${ }^{1}$, Z. Wilhelm de Beer ${ }^{2}$, Lori G. Eckhardt ${ }^{1}$ and Michael J. Wingfield ${ }^{2}$
}

(1) Forest Health Dynamics Laboratory, School of Forestry and Wildlife Sciences, Auburn University, Alabama, 36849, USA

(2) Department of Microbiology and Plant Pathology, Forestry and Agricultural Biotechnology Institute (FABI), University of Pretoria, Pretoria, South Africaa

\section{Z. Wilhelm de Beer}

Email: wilhelm.debeer@fabi.up.ac.za

\begin{abstract}
During the course of a survey of fungi in loblolly pine (Pinus taeda) roots in Georgia, USA, a species of Ophiostoma morphologically similar to O. pluriannulatum, was isolated. Morphological characteristics and DNA sequence comparisons were used to identify the fungus. The isolates produced perithecia with unusually long necks similar to those of $O$. pluriannulatum but they had few or no annuli. DNA sequences for the ribosomal internal transcribed spacer regions 1 and 2 were identical to those of $O$. pluriannulatum. Sequence data of the $\beta$-tubulin gene region revealed the absence of intron 4 and presence of intron 5, distinguishing the isolates from $O$. pluriannulatum, which has intron 4 but not intron 5. Phylogenetic analyses of the $\beta$-tubulin sequences showed that the isolates from loblolly pine roots grouped together in a lineage distinct from $O$. multiannulatum and $O$. subannulatum, both of which lack intron 4 and have intron 5 . The fungus is consequently described as $O$. sparsiannulatum sp. nov., a novel taxon in the O. pluriannulatum complex.
\end{abstract}

\section{Introduction}

Species accommodated in the Ophiostomatales (Ascomycetes) are generally known as blue-stain fungi. This is due to the discoloration that most of these species cause on lumber (Seifert 1993) and sapwood of trees infested by scolytine bark beetles (Coleoptera: Scolytinae) or molytine weevils (Coleoptera: Molytinae), which act as their vectors (Malloch and Blackwell 1993). Some of these fungi are also pathogens of trees, e.g., Ophiostoma ulmi and O. novo-ulmi causing Dutch elm disease (Brasier 1991), while others are not or only mildly pathogenic to trees (Zhou et al. 2002).

Three teleomorph genera are recognized in the Ophiostomatales: Grosmannia that have Leptographium anamorphs, Ceratocystiopsis with Hyalorhinocladiella anamorphs, and Ophiostoma in which both Sporothrix and/or Pesotum anamorphs are found (Zipfel et al. 2006). Of these, Ophiostoma is the largest and most variable genus, and it includes some monophyletic lineages of species that share similar morphological characters. One such lineage has been referred to as the O. pluriannulatum complex (Zipfel et al. 2006).

The O. pluriannulatum complex is one of the lesser-known and studied groups in the Ophiostomatales, but DNA sequences from some recent studies have revealed several previously unknown species relationships in the complex. In a phylogeny based on the internal transcribed spacer (ITS) region sequences of the ribosomal RNA operon, Villarreal et al. (2005) showed that $O$. 
multiannulatum, $O$. subannulatum, and $O$. conicola grouped close to $O$. pluriannulatum, the oldest species in the complex. Based on mating compatibility and ITS sequences, Thwaites et al. (2005) suggested that at least four more species exist in the complex. These included $O$. perfectum and an undescribed species referred to as Ophiostoma sp. E. They suggested that the other isolates from their study possibly represent $O$. californicum and $O$. populinum (Thwaites et al. 2005). Zipfel et al. (2006) added $O$. carpenteri to the complex based on ribosomal large subunit (LSU) and partial $\beta$ tubulin sequences, while Kamgan et al. (2008) described a new species, O. longiconidiatum, from native hardwood trees in South Africa. Most of these species are characterized by ascomata with long, fine necks that typically bear annuli (Davidson 1935; DeVay et al. 1968; Hedgcock 1906; Kamgan et al. 2008; Livingston and Davidson 1987).

During the course of investigations considering pine decline in the southeastern United States, isolates of an Ophiostoma species were collected from loblolly pine (Pinus taeda L.) roots in Fort Benning, Georgia. The morphology of these isolates superficially resembled $O$. pluriannulatum and related species. The aim of this study was to identify the new isolates to the species level using morphological criteria and DNA sequence comparisons.

\section{Materials and Methods}

\section{Isolation of fungi}

Loblolly pine roots were excavated at Fort Benning Military Reservation, Georgia, USA, using a two-lateral root sampling approach described by Otrosina et al. (1999) and modified by Eckhardt et al. (2007). Roots were surface disinfested in a solution of ethanol, commercial bleach, and distilled water (80:10:10, v:v:v), rinsed in tap water, and then plated on malt extract agar (MEA, $20 \mathrm{~g}$ malt extract, $15 \mathrm{~g}$ agar/L) and MEA amended with cycloheximide and streptomycin (CSMA) (Zhou et al. 2004a). Ophiostomatoid fungi were recognized by their characteristic perithecia or conidiophores and transferred to fresh CSMA or MEA. All isolates are maintained in the culture collection (CMW) of FABI, University of Pretoria, South Africa. Type specimens were deposited in National Collection of Fungi (PREM), Pretoria, South Africa, and ex-type cultures in the Centraalbureau voor Schimmelcultures (CBS), Utrecht, The Netherlands.

\section{Morphology}

To assess characters of the mycelium, ascomata, and conidia, isolates were grown on oatmeal agar (OA; $30 \mathrm{~g}$ Jungle brand oats/L with $15 \mathrm{~g} / \mathrm{L}$ agar), 2\% MEA or pine twig agar (PTA; water agar 15 $\mathrm{g} / \mathrm{L}$ with twice-autoclaved Mexican weeping pine [Pinus patula Schltdl. \& Cham.] twigs embedded into the agar). Fungal characteristics were measured using a Zeiss Axioskop 2 microscope with phase contrast and differential interference contrast (DIC) microscopy, and data were collected using the software package AxioVision Release 4.4.1.0. (Carl Zeiss Microimaging, München, Germany). Fifty measurements were made of each structure, and maxima, minima, and means determined.

Agar plugs ( $5 \mathrm{~mm}$ diameter) taken from actively growing cultures were transferred to fresh MEA plates, incubated at temperatures ranging from 5 to $35^{\circ} \mathrm{C}$ at five-degree intervals using three replicate plates for each temperature. Radial growth was measured every 2 days until the colonies reached the edges of the plates.

Single ascospore isolates were obtained by streaking spore droplets on MEA plates. Germinating ascospores were transferred to new MEA plates. These were crossed in all possible combinations (Zhou et al. 2004b) to test whether the fungus was homo- or heterothallic. 


\section{DNA extraction, PCR and sequencing}

Genomic DNA was prepared for PCR from fresh mycelium taken from cultures on MEA using PrepMan Ultra Reagent (Applied Biosystems, Foster City, California, USA), following the protocol described by Aghayeva et al. (2004). The ITS regions were amplified using the primers ITS1F (Gardes and Bruns 1993) and ITS4 (White et al. 1990) and the $\beta$-tubulin gene region using the primers T10 (O’Donnell and Cigelnik 1997) together with Bt2b (Glass and Donaldson 1995).

Amplifications were performed in an Eppendorf MasterCycler Personal thermal cycler (Eppendorf, Hamburg, Germany) under the following conditions: an initial denaturation at $95^{\circ} \mathrm{C}$ for $2 \mathrm{~min}$, followed by 40 cycles of $95^{\circ} \mathrm{C}$ for $30 \mathrm{sec}, 50^{\circ} \mathrm{C}$ annealing for $30 \mathrm{sec}$, and $72^{\circ} \mathrm{C}$ extension for $60 \mathrm{sec}$, with a final extension period of $8 \mathrm{~min}$ at $72^{\circ} \mathrm{C}$. Reaction mixtures, $50 \mu \mathrm{L}$ total volume, consisted of $5 \mu \mathrm{L} 10 \times$ PCR reaction buffer (JMR Holdings, London, UK), $2.5 \mathrm{mM} \mathrm{MgCl} 2,10 \mathrm{mM}$ dNTPs, 10 $\mu \mathrm{M}$ of each primer, $2.5 \mathrm{U}$ Taq polymerase (SuperTherm; JMR Holdings) and $4 \mu \mathrm{L}$ of genomic DNA. Amplification success was assessed on a $1 \%(\mathrm{w} / \mathrm{v})$ agarose gel stained with ethidium bromide and visualized under UV light. PCR products were purified with the High Pure PCR Purification Kit (Roche Pharmaceuticals, Basel, Switzerland) according to the manufacturer's protocol. Amplicons were then cycle sequenced using the Big Dye ${ }^{\mathrm{TM}}$ Terminator v. 3.0 cycle sequencing premix kit (Applied Biosystems) with the primers noted above, and analyzed on an ABI PRISMTM 377 or ABI PRISMTM 3100 Genetic Analyzer (Applied Biosystems).

Electropherograms of the resolved sequences were visualized, and contigs of forward and reverse sequences compiled using MEGA 4.0.1 (Tamura et al. 2007). Sequences were subjected to BLAST searches in NCBI GenBank to determine similarity to published sequences. Appropriate sequences were downloaded and datasets compiled in MEGA 4.0.1. Alignments were done using the E-INS-I strategy in the online version of MAFFT 6 (Katoh and Toh 2008) (http://align.bmr.kyushuu.ac.jp/mafft/online/server/). For the $\beta$-tubulin gene region, manual adjustments of the alignment were performed in MEGA 4.0.1 using the translation option to ensure appropriate alignment of exons based on amino acid sequences. All sequences generated in this study were deposited in NCBI GenBank.

\section{Phylogenetic analyses}

Aligned sequences of the ITS and $\beta$-tubulin gene regions were subjected to phylogenetic modeling using maximum parsimony (MP), maximum likelihood (ML), and neighbor-joining (NJ) in PAUP 4.0 b10 (Sinauer, Sunderland, Massachusetts, USA), and Bayesian analyses using MrBayes 3.1.2 (Ronquist and Huelsenbeck 2003). The most appropriate substitution models for both gene regions were selected using the Akaike information criterion (AIC) in ModelTest 3.7 (Posada and Crandall 1998) for ML and NJ analyses, and MrModelTest 2 (Nylander 2004) for Bayesian analyses. For MP, ML, and NJ, 1,000 bootstrap replicates were performed to test branch stability. Bayesian analyses consisted of four independent runs of 10 million generations each using duplicate Monte Carlo Markov chain searches with four chains. Trees were saved every 100 generations. Burnin was determined for each dataset using Tracer 1.4 (http://evolve.zoo.ox.ac.uk/software.html).

\section{Results}

\section{Isolation of fungi}

Three isolates of an unidentified Ophiostoma sp. were recovered from loblolly pine roots. These isolates were cycloheximide-tolerant, and were found in association with other cycloheximidetolerant taxa including Leptographium spp. and Penicillium spp. 


\section{Morphology}

Isolates produced abundant aerial hyphae bearing dry, micronematous conidia typical of the anamorph genus Sporothrix. Long-necked, darkly pigmented ascomata formed abundantly in culture within 8 days, but only in crosses between single conidial isolates. The ascomata were variable in size, with large and small ascomata producing droplets with viable ascospores. Colonies tended to darken with age. Morphological characteristics were consistent with those of the $O$. pluriannulatum complex (Table 1), although annuli on the ascomatal necks were few in number or lacking. The ascospores were slightly smaller than those reported for the other species most similar to the isolates from loblolly pine roots (Table 1).

Table 1. Comparison of characters of Ophiostoma sparsiannulatum with related and morphologically similar species.

\begin{tabular}{|c|c|c|c|c|c|c|}
\hline Chracter & Subchracter & O. sparsianda sum $s$. sov. & O. phosantalasum & 0. mol skanulatum & o. calfornioum & O. nabasudasum \\
\hline \multirow[t]{5}{*}{ Peribecia } & Neck lengh (mm) & $0.8-1.4(-8)$ & $(0.9-) 0.5(-20)$ & 40.85 & $0.6-1.1$ & $0.2-1.2(-0 \infty 2.2)$ \\
\hline & Nauli & $0-2(-4)$ & 3-8 & $6-9$ & 0 so seveal & $1-2(-4)$ \\
\hline & Coloe of base & Drik boown wo bladk & Blaxk & Blaxk & Hyaline & Bladk \\
\hline & $\begin{array}{r}\text { Dimeser of } \\
\text { base }(\mu \mathrm{m})\end{array}$ & $(54) \div 04-166(201)$ & $(90) \times 20 \times(200)$ & $170-275$ & $130-175$ & $75-200$ \\
\hline & $\begin{array}{l}\text { Orammentaxioes } \\
\text { of bore }\end{array}$ & $\begin{array}{l}\text { Brownich byphae } \\
\text { up so } 200, \mathrm{pm} \text { loog }\end{array}$ & $\begin{array}{l}\text { Unornmented of with } \\
\text { a few seperie, pale } \\
\text { boown hyphae }\end{array}$ & $\begin{array}{l}\text { Surface roughesed } \\
\text { with globoce cells }\end{array}$ & Shoodh & $\begin{array}{l}\text { Unoernamentod of } \\
\text { with a few sepease, } \\
\text { beownith hyphal hairs }\end{array}$ \\
\hline \multirow[t]{3}{*}{ Ascoepores } & Shape & Allansoid & Renifcem & Reaifoen & Ourved & $\begin{array}{l}\text { Allmoo id to becadly } \\
\text { hanne }\end{array}$ \\
\hline & Iength (um) & $(2.2-\beta, \alpha-4.0)$ & $(4.0-) 4.5(-5.0)$ & $28-3.8$ & 3.0 .45 & $3.5-5.0(-6.0)$ \\
\hline & Width ( $\mu \mathrm{m})$ & $(0.7-)+. \alpha-1.6)$ & $(1.5-) 4.5(-1.7)$ & $1.2-1.4$ & $1.0-1.3$ & $1.0-25$ \\
\hline Anamorph & & Spoovodietx & Spoorotirix & Sporotiolx & Spavoshotx & $\begin{array}{l}\text { Spowotirix } \\
\text { (with sticky spores) }\end{array}$ \\
\hline \multirow[t]{3}{*}{ Cosidia } & Ienght (um) & $2.7-9.2$ & $4.6-18.0$ & $60-25.0$ & $3.0-18.0$ & $2.0-6.0$ \\
\hline & Width (um) & $0.8-23$ & $1.5-3.0$ & $20-3.2$ & $1.2-1.6$ & $1.0-4.0$ \\
\hline & Secoodary coesitia & Present & Present: & Not poesent & Present & Present \\
\hline Hos: & & Plswes saxda & Quercus sp, Plese sp. & Plawe spo & Prowest domeatsea & $A b N=s p$ \\
\hline Distribusion & & Goorgia, USA & $\begin{array}{l}\text { Soutbeastem USA, } \\
\text { New Zealasd }\end{array}$ & Souteastem USA & Califoenia, USA & Idabo, USA \\
\hline Btubulin introes" & & -15 & 46 & -15 & No B tubulin saquexces & -15 \\
\hline $\begin{array}{l}\text { Mogpbologioal } \\
\text { descriposes }\end{array}$ & & This stady & $\begin{array}{l}\text { Hadecock 1906; } \\
\text { Upadhyay } 1981\end{array}$ & Davidwe 1935 & $\begin{array}{l}\text { Devay a al } 1968 \text {; } \\
\text { Upadhyay } 1981\end{array}$ & $\begin{array}{l}\text { Livingsoe asd } \\
\text { Davidsce } 1987\end{array}$ \\
\hline
\end{tabular}

\section{PCR and sequencing}

Amplicons of the ITS regions yielded 618 bp of readable sequence data with NCBI GenBank accession numbers FJ906816-FJ906818. These sequences were identical to those for $O$. pluriannulatum published in GenBank, and similar to several other Ophiostoma spp. Amplicons of the $\beta$-tubulin gene yielded 575 bp of readable sequence data (FJ907176-FJ907178), which shared $93 \%$ homology with $O$. subannulatum, the closest match in GenBank. The partial $\beta$-tubulin sequences of these isolates included $14 \mathrm{bp}$ of exon 3 , no intron 3 , exon 4 ( $27 \mathrm{bp}$ ), no intron 4 , exon 5 (42 bp), intron 5 (49 bp), and $443 \mathrm{bp}$ of the $5^{\prime}$ end of exon 6.

\section{Phylogenetic analyses}

For the ML and NJ analyses of the ITS dataset, the $\mathrm{TrN}+\mathrm{G}$ substitution model was selected. For the Bayesian analysis, GTR $+\mathrm{I}+\mathrm{G}$ was selected. The aligned ITS dataset consisted of 742 characters and confirmed the placement of the isolates in the genus Ophiostoma and in the O. pluriannulatum complex (Fig. 1). ITS sequences for the isolates from $P$. taeda roots were identical to those of $O$. pluriannulatum sensu stricto, but differed in nine bases from $O$. multiannulatum and six bases from O. subannulatum. The $O$. californicum and Ophiostoma sp. E isolates of Thwaites et al. (2005) formed well-supported clades within the larger $O$. pluriannulatum clade, distinct from the isolates from loblolly pine roots. 


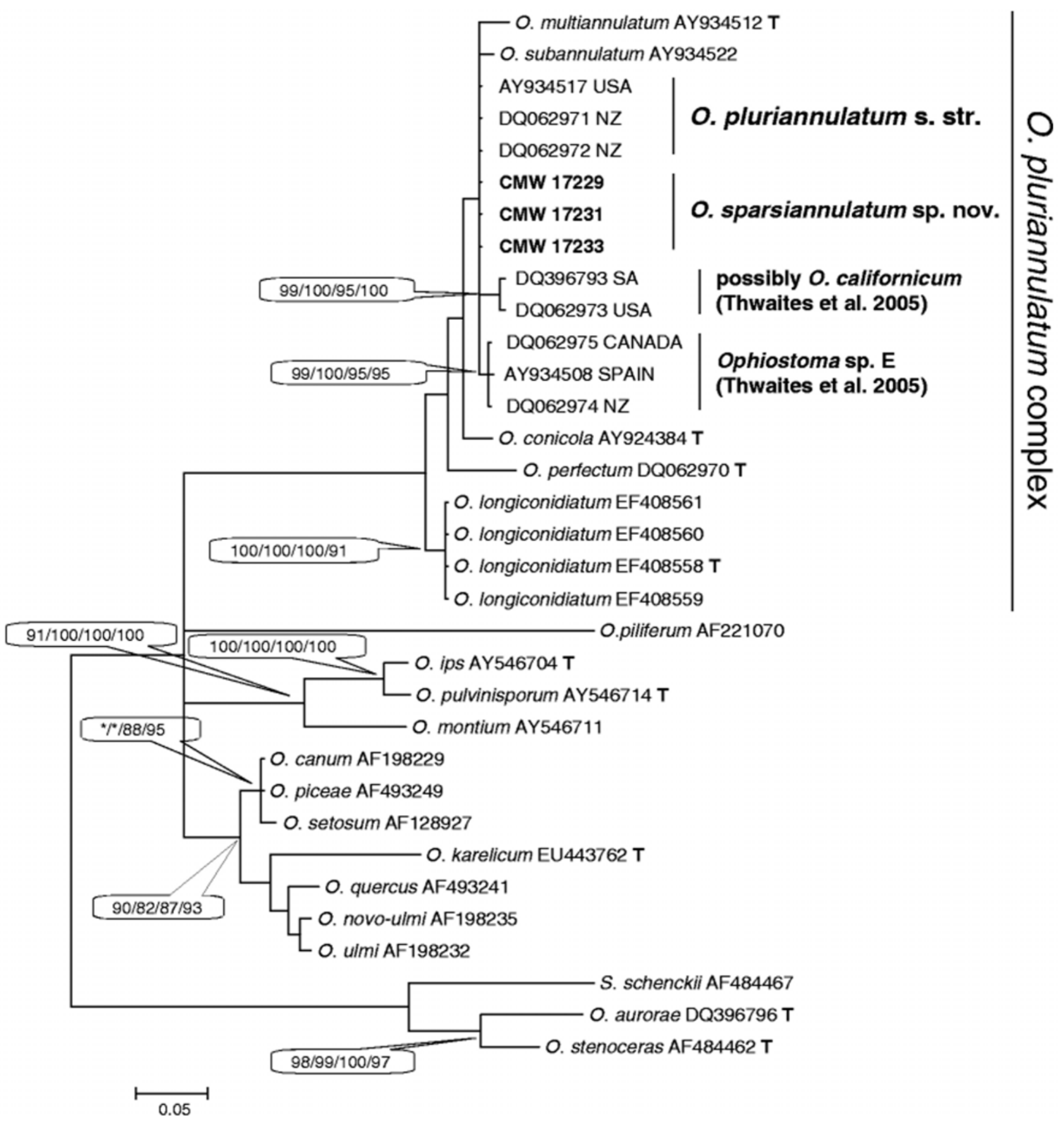

Fig. 1. Bayesian tree of ITS sequences of selected Ophiostoma and Sporothrix isolates, representing all the major lineages in Ophiostoma. Sequences obtained from the present study are printed in bold type. Accession numbers are presented for all sequences obtained from GenBank. Branch support is indicated by bootstrap analyses (1,000 replicates) for MP, ML, and NJ analyses, and posterior probabilities for Bayesian analysis, respectively. *Bootstrap support $<70 \%$, T ex-type isolates.

The aligned $\beta$-tubulin data used for phylogenetic analyses consisted of 354 characters, including exons 4,5 and 6, interspersed by introns 4 and 5 . In the loblolly pine root isolates, intron 4 was lacking and intron 5 was present, and this was the same for $O$. multiannulatum and $O$.

subannulatum. Ophiostoma pluriannulatum, O. carpenteri, and O. piliferum had intron 4 and lacked intron 5, thus separate phylogenetic analyses were conducted for datasets including (Fig. 2a) and excluding (Fig. 2b) species with intron arrangements different from the isolates from $P$. taeda roots. For ML and NJ analyses, the $\mathrm{TrN}+\mathrm{I}$ model was selected for the $\beta$-tubulin dataset including $O$. pluriannulatum, $O$. carpenteri, and $O$. piliferum, and for the $\beta$-tubulin dataset excluding these three taxa, the HKY $+\mathrm{I}$ model was selected. For the Bayesian analysis, GTR $+\mathrm{I}+\mathrm{G}$ was selected for the inclusive dataset, and $\mathrm{HKY}+\mathrm{I}$ for the exclusive dataset. 

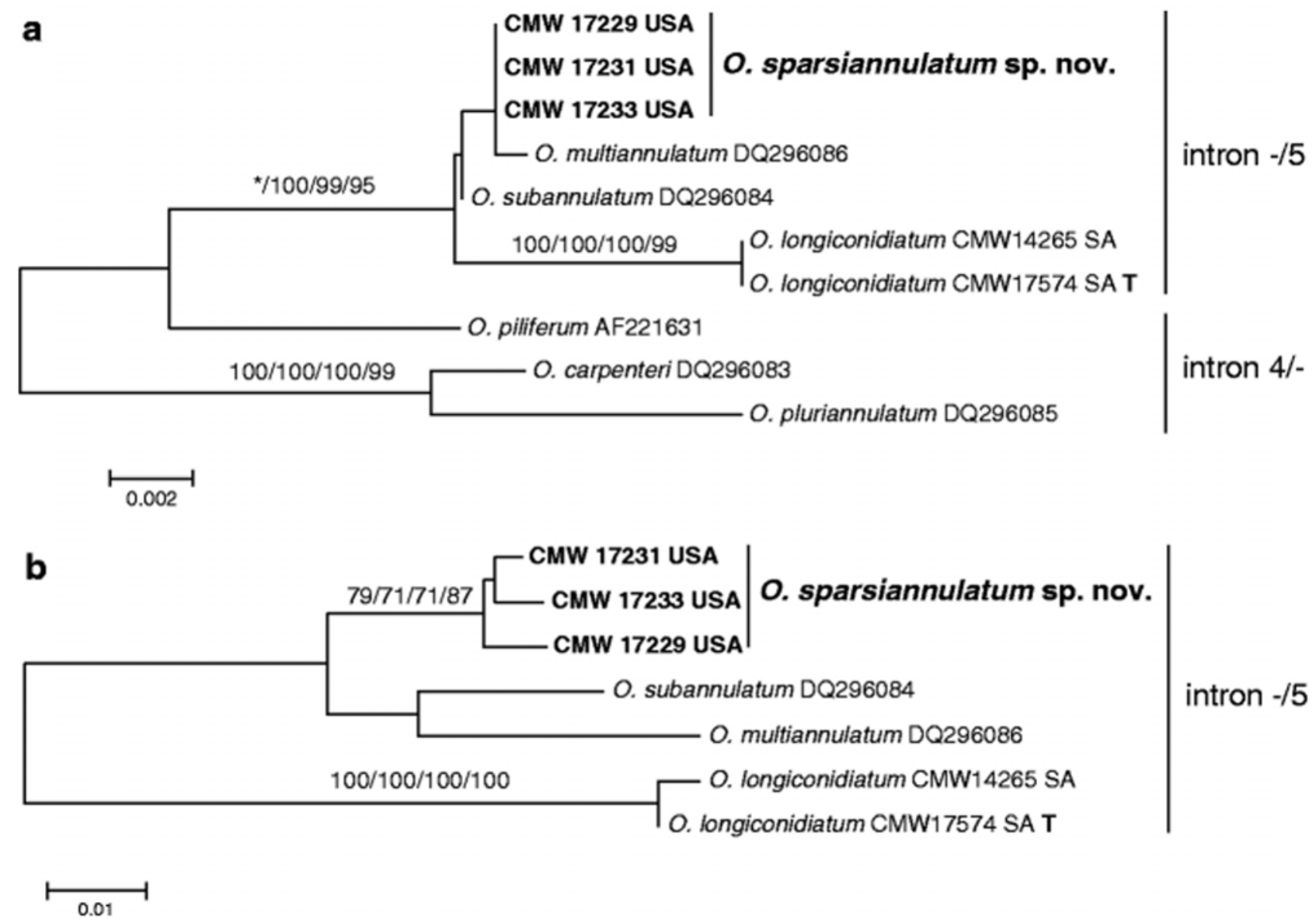

Fig. 2. Bayesian trees of $\beta$-tubulin sequences of species from the $O$. pluriannulatum complex, including exons 4, 5, and 6, as well as the introns as specified. Accession numbers are presented for all sequences obtained from GenBank. Branch support is indicated by bootstrap analyses $(1,000$ replicates) for MP, ML, and NJ analyses, and posterior probabilities for Bayesian analysis, respectively. *Bootstrap support $<70 \%$, T ex-type isolates. a Dataset including species that have intron 4 but not intron 5, as well as those lacking intron 4, but with intron 5. b Dataset including only species without intron 4 and with intron 5

Phylogenetic trees generated from the $\beta$-tubulin sequence data showed that the isolates under investigation were distinct from $O$. pluriannulatum sensu stricto (Fig. 2a). The pattern of exons and introns was similar to that of $O$. multiannulatum and $O$. subannulatum (Fig. 2a), but the sequences were distinct from the latter two species, forming a lineage with strong statistical support in the analyses that included only species with intron 4 (Fig. 2b).

\section{Taxonomy}

The Ophiostoma species from loblolly pine roots is morphologically similar to $O$. pluriannulatum and related species (Table 1). However, based on DNA and morphological comparisons, the new isolates represent a novel species, described here as follows:

Ophiostoma sparsiannulatum Zanzot, Z.W. de Beer and M.J. Wingf., sp. nov. MycoBank MB 515290. Figs. 3 and 4.

Etymology: The name refers to the fact that annuli are produced sparsely on the ascomatal necks of this fungus. 

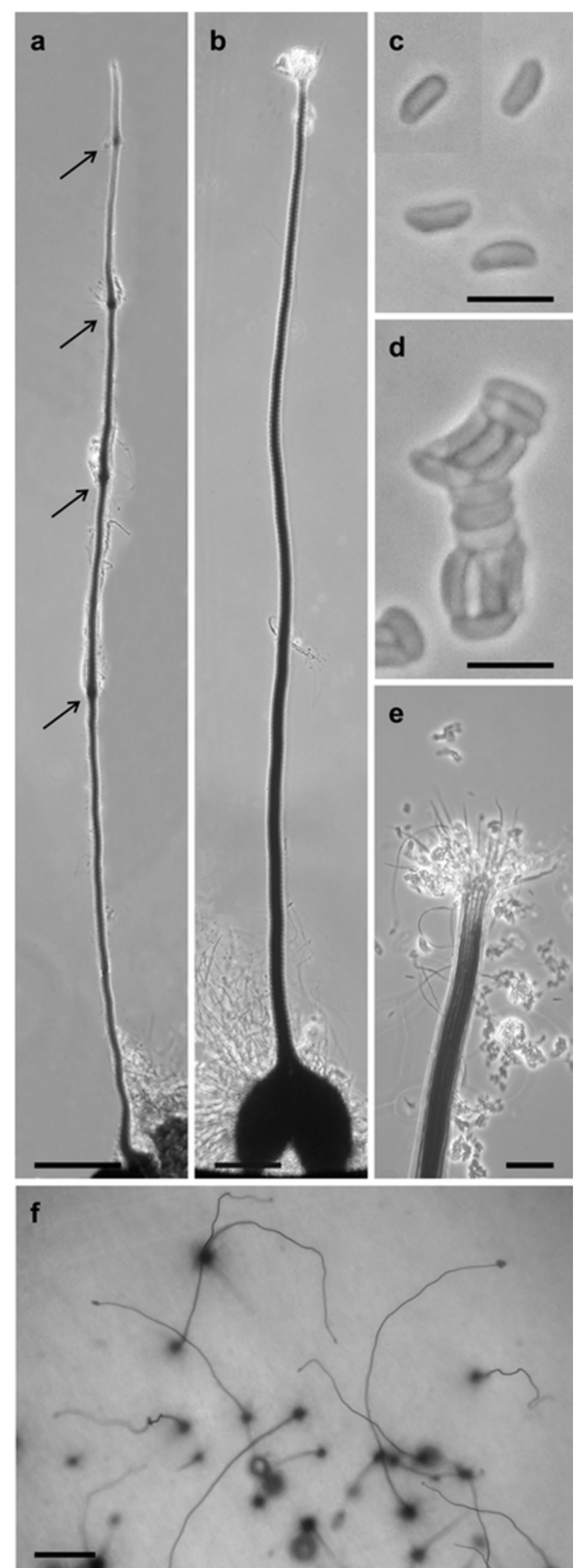

Fig. 3. Teleomorph of Ophiostoma sparsiannulatum (ex-holotype, CBS 122815). a Neck of mature ascoma with annuli (arrows) present (bar $100 \mu \mathrm{m})$. b Mature ascoma (bar $100 \mu \mathrm{m})$. c, d Ascospores (bars $5 \mu \mathrm{m}$ ). e Ostiolar hyphae surrounding ostiole at apex of ascomatal neck (bar $20 \mu \mathrm{m})$. $\mathbf{f}$ Ascomata submerged in pine twig agar (bar $1 \mathrm{~mm}$ ). 

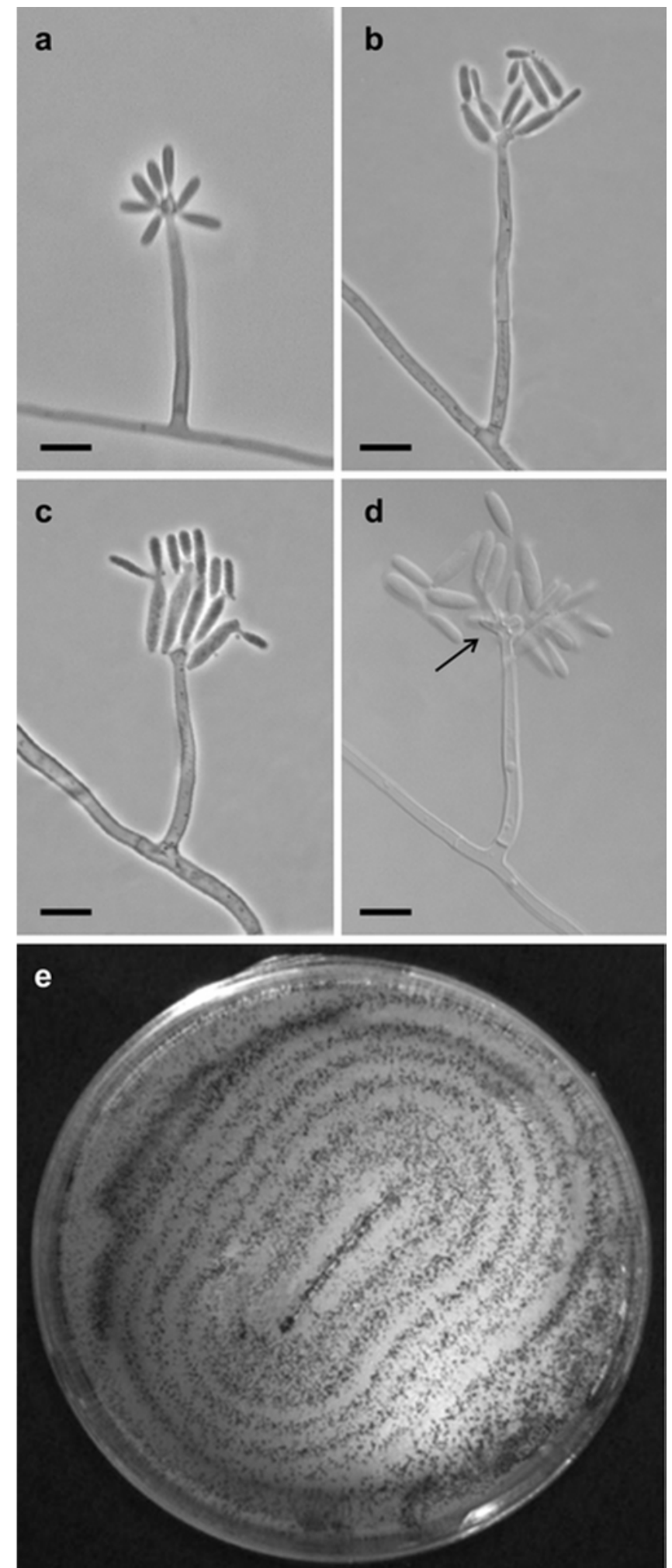

Fig. 4. Sporothrix anamorph of Ophiostoma sparsiannulatum (ex-holotype, CBS 122815). a-c Different stages of conidiophores with conidia, showing the development of secondary conidia (phase contrast, bars $5 \mu \mathrm{m}$ ). d Conidiogenous cell with conidia formed on denticles (DIC, bar 5 $\mu \mathrm{m})$. e Culture on oatmeal agar, showing concentric rings of ascomata.

Description: Bases ascomatum atrobrunneae vel nigrae, globosae, (54-)104-166(-201) $\mu \mathrm{m}$ diametro. Colla ascomatum atrobrunnea vel nigra, (500-)800-1,400(-1,850) $\mu \mathrm{m}$ longa, annulis $0-4$, apice (7-)10-17(-21) $\mu \mathrm{m}$, basi (13-)27-48(-65) $\mu \mathrm{m}$ diametro. Ascomata nonnulla in agaro immersa colla valde longiora usque ad 8,600 $\mu \mathrm{m}$ habent. Hyphae ostiolares divergentes, hyalinae $(18-) 32-62(-80) \mu \mathrm{m}$ longa. Ascosporae hyalinae, allantoideae, $(2.2-) 2.8-3.4(-4.0) \times(0.7-) 0.9-$ 
1.1(-1.6) $\mu \mathrm{m}$, in massa pallide flava mucosa in apice cumulantes. Anamorpha Sporothrix inter ascomata in massis albis, floccosis, abundanter, crescens. Conidiophorae (9-)13-52(-150) $\mu \mathrm{m}$ longae, cellulae conidiogenae denticulis $(0.7-) 0.8-1.3-(1.6) \mu \mathrm{m}$ longis. Conidia plerumque ovoidea vel obovoidea, $(2.7-) 3.8-6.7(-9.2) \times(0.8-) 1-1.8(-2.3) \mu \mathrm{m}$, saepe conidia secundaria emittentia.

Colony hyaline at first, darkening with age and with copious white floccose aerial growth of the anamorph, typically forming concentric rings (Fig. 4e). Mycelium aerial and submerged. Optimal temperature for growth $25^{\circ} \mathrm{C}$, no growth at $35^{\circ} \mathrm{C}$. Hyphae smooth, not constricted at septa. Ascomata typically produced within 8 days, and only in crosses between single spore isolates, suggesting heterothallism. Ascomatal bases dark brown to black, globose, bases (54-)104-166(201) $\mu \mathrm{m}$ in diameter (Fig. 3b), brownish ornamental hyphae up to $200 \mu \mathrm{m}$ long. Ascomatal necks dark brown to black, $(500-) 800-1,400(-1,850) \mu \mathrm{m}$ long with annuli absent or occasionally $1-4$ present (Fig. 3a). Some submerged perithecia observed on PTA (Fig. 3f) have much longer necks, as long as $8,600 \mu \mathrm{m}$. Diameter of the necks (7-)10-17(-21) $\mu \mathrm{m}$ at the apex and (13-)27-48-(65) $\mu \mathrm{m}$ at the base. Ostiolar hyphae divergent, hyaline, (18-)32-62(-80) $\mu \mathrm{m}$ long (Fig. 3e). Asci not observed. Ascospores accumulating in a clear white mucilaginous mass at the ascomatal apex, turning light yellow with age, hyaline, allantoid, $(2.2-) 2.8-3.4(-4.0) \times(0.7-) 0.9-1.1(-1.6) \mu \mathrm{m}($ Fig. $3 \mathrm{c}, \mathrm{d})$.

Sporothrix anamorph: growing abundantly amongst the perithecia, in white fluffy masses. Conidiophores of variable length, (9-)13-52(-150) $\mu \mathrm{m}$ (Fig. 4a-d), conidiogenous cells with denticles (0.7-)0.8-1.3(-1.6) $\mu \mathrm{m}$ long (Fig. 4d). Conidia typically ovoid-obovoid with a basal abscission collar evident, $(2.7-) 3.8-6.7(-9.2) \times(0.8-) 1-1.8-(2.3) \mu \mathrm{m}$, often giving rise to secondary conidia (Fig. 4b-d).

Specimens examined: USA, Georgia, Fort Benning, from roots of Pinus taeda, July 2004, L.G. Eckhardt. Holotype PREM 59847, ex-holotype culture CBS 122815=CMW 17231, Paratype PREM 59848, ex-paratype culture CBS 122816=CMW 17233. Additional culture CMW 17229.

Notes: Morphological differences between $O$. sparsiannulatum and similar species are listed in Table 1. Ophiostoma pluriannulatum differs from $O$. sparsiannulatum in having longer ascospores and longer conidia, while $O$. multiannulatum has longer perithecial necks, greater numbers of annuli, longer conidia, no secondary conidia, and characteristic globose cells on the perithecial bases. Ophiostoma californicum has hyaline bases that are not ornamented as opposed to the dark bases with ornamental hyphae in $O$. sparsiannulatum. Of all these species, $O$ subannulatum is most similar to $O$. sparsiannulatum, but its conidia are generally shorter and rounder than those of the latter species. The conidia of $O$. subannulatum are also produced in slimy masses (Livingston and Davidson 1987), while those of O. sparsiannulatum, O. pluriannulatum, and O. multiannulatum are borne in dry, floccose clusters.

\section{Discussion}

This investigation revealed a new species of Ophiostoma isolated from roots of loblolly pine that is morphologically similar and closely related to O. pluriannulatum. Recognition of the new species initially rested strongly on DNA sequence comparisons with $O$. pluriannulatum and related species. Yet having recognized that it represented a novel taxon, it is also possible to distinguish $O$. sparsiannulatum from related species based on morphological characteristics.

DNA sequence comparisons, especially the ITS regions, are often used to address species level questions in fungi, including the Ophiostomatales (De Beer et al. 2003; Harrington et al. 2001). However, in the present study, ITS sequences did not distinguish satisfactorily between $O$. sparsiannulatum and other species in the complex. This is not unique as there are other cases where 
ITS sequences have failed to resolve closely related species within Ophiostoma (Chung et al. 2006; Harrington et al. 2001). Partial $\beta$-tubulin sequences, including intron data, are now routinely used to improve resolution when comparing closely related species (Gorton et al. 2004; Grobbelaar et al. 2009). The presence or absence of introns within the $\beta$-tubulin gene region have been shown to be constant within major lineages of the Ophiostomatales, and can be used as a tool to distinguish between these lineages (Zipfel et al. 2006). However, results from the present study showed for the first time that two closely related Ophiostoma species (O. pluriannulatum and O. subannulatum) can have identical ITS sequences but a different intron/exon composition in the $\beta$-tubulin gene. This emphasizes the fact that extreme care should be taken when aligning $\beta$-tubulin sequences, always ensuring that exon data are aligned appropriately based on their amino acid sequences. The risk here lies in the fact that a small exon might not be recognized by the alignment program if it is not designated. This is especially true when an alignment is enforced onto longer introns on either side of the exon. The exon sequence would thus be aligned with intron sequences and resulting phylogenies would not accurately reflect the evolution of the gene region.

An important morphological characteristic in most members of the $O$. pluriannulatum complex is that they have long perithecial necks with annuli. These annuli are likely vestiges of ostiolar hyphae through which the necks have proliferated (DeVay et al. 1968; Thwaites et al. 2005). Both $O$. pluriannulatum and $O$. multiannulatum have perithecia with several annuli. While $O$. sparsiannulatum has perithecial necks similar in length to these species, it has no or very few annuli. In this regard, it is most similar to O. subannulatum.

The importance of annuli as a diagnostic character for Ophiostoma spp. has been debated, with their importance discounted (De Hoog 1974) or emphasized (Upadhyay 1981). Phylogenetic inference based on DNA sequences support the $O$. pluriannulatum complex as a monophyletic clade, now accommodating seven Ophiostoma spp. with annulate perithecial necks: $O$. sparsiannulatum, $O$. pluriannulatum, O. multiannulatum, O. californicum, O. subannulatum, O. longiconidiatum (Thwaites et al. 2005; Zipfel et al. 2006; Kamgan et al. 2008), and an as yet undescribed species, Ophiostoma sp. E (Thwaites et al. 2005). Species in the complex that do not form long necks with annuli are O. carpenteri (Hausner et al. 2003), O. conicola (Marmolejo and Butin 1990), and $O$. perfectum (Davidson 1958). The position of $O$. perfectum is uncertain, since ITS sequences of the ex-type isolate (CBS 636.66) produced by Thwaites et al. (2005) and Villarreal et al. (2005) are very different from each other. The sequence produced by Thwaites et al. (2005) is included in our analyses (Fig. 1), but those of Villarreal et al. (2005) correspond to O. floccosum, which groups outside the O. pluriannulatum complex and closer to O. piceae (Zipfel et al. 2006). Furthermore, De Hoog (1974) described a synnematous synanamorph from the ex-type isolate of O. perfectum, while Davidson (1958) only mentioned a Sporothrix anamorph in his original description. It is thus possible that the ex-type isolate represents a mixed culture. The relatedness of $O$. perfectum, $O$. carpenteri, and $O$. conicola to the $O$. pluriannulatum complex should be re-evaluated with critical study of the type material, and where possible additional isolates of each species. Such a study would reveal whether annuli on elongated perithecial necks should be considered a unifying characteristic of the $O$. pluriannulatum complex.

The first species to be described in the $O$. pluriannulatum complex was $O$. pluriannulatum sensu stricto, which was isolated from stained northern red oak (Quercus rubra L.) sapwood (Hedgcock 1906). This species has been recorded by far the most often of all species in the complex, and also from many other hardwood genera and species in North America (Appel et al. 1990; Davidson 1935; Griffin 1968), Europe (Gregor 1932) and Japan (Aoshima 1965). The fungus has, furthermore, been described from conifers such as pine, spruce, and fir from North and Central America (Davidson 1935; Zhou et al. 2004b), Europe (Mathiesen-Käärik 1953; Romón et al. 2007), Japan (Aoshima 1965), New Zealand (Thwaites et al. 2005), and South Africa (Zhou et al. 2006). Identification of $O$. pluriannulatum in most of these reports was based on morphology, and only in 
more recent cases on ITS sequences (Thwaites et al. 2005; Romón et al. 2007; Villarreal et al. 2005; Zhou et al. 2006). Results of the present study reinforce the fact that additional sequence data such as those for the $\beta$-tubulin gene region are required to delineate species in the complex. Clearly, overlapping morphological features in many of these species have resulted in isolates reported in the older literature as $O$. pluriannulatum, while they could represent other species in the complex. For example, the fungus reported by Verrall $(1939,1941)$ from loblolly pine in Georgia, and for which cultures are no longer available, could have been the same as O. sparsiannulatum, given that it was isolated from the same host species in the same region.

Ophiostoma pluriannulatum has been isolated from several wood- and bark-infesting insects and their galleries (Appel et al. 1990; Mathiesen-Käärik 1953; Romón et al. 2007; Verrall 1941; Zhou et al. 2004b, 2006). Again, the identifications of the fungus were based on morphology and only in the recent cases on ITS sequence. It is, therefore, impossible to draw meaningful conclusions relating to the insect-fungus interactions in this complex, apart from the fact that most species appear to be associated with bark beetles and nitidulids. Any conclusions regarding the specificity of these insect-fungus-host interactions will only be possible when identifications of the fungal species have been resolved based on sufficiently variable gene regions.

Ophiostoma sparsiannulatum is known only from the roots of loblolly pine damaged by various root-infesting insects. Given that these insects specialize on Pinus spp., it seems likely that the fungus will share this habit. While $O$. sparsiannulatum has been recovered from the living roots of declining loblolly pine trees, its recovery was infrequent. This suggests that it is not an important contributing factor in southern pine decline (Eckhardt et al. 2007; Menard 2007). Virtually no pathogenicity data are available for the members of the $O$. pluriannulatum complex, but these fungi are not considered to be pathogens (Davidson 1935; Hedgcock 1906). Nonetheless, further studies should include root inoculations with $O$. sparsiannulatum to evaluate its capacity to infect roots, as well as consideration of how it is transmitted and whether it may infect other hosts.

\section{Acknowledgments}

We thank the United States Department of Defense, via Fort Benning Military Reservation for funding the research that led to the discovery of this species. We also acknowledge members of the Tree Protection Cooperative Program (TPCP) and the DST/NRF Centre of Excellence in Tree Health Biotechnology (CTHB), Forestry and Agricultural Biotechnology Institute, University of Pretoria, for financial support. Mr. Roger Menard of the USDA Forest Service-Forest Health Protection in Pineville, Louisiana, provided invaluable technical support and Dr. Hugh Glen provided the Latin diagnosis.

\section{Literature Cited}

Aghayeva DN, Wingfield MJ, De Beer ZW, Kirisits T (2004) Two new Ophiostoma species with Sporothrix anamorphs from Austria and Azerbaijan. Mycologia 96:866-878.

Aoshima K (1965) Studies on wood-staining fungi of Japan. [In Japanese with English summary]. $\mathrm{PhD}$ thesis, University of Tokyo, Tokyo.

Appel DN, Kurdyla T, Lewis JR (1990) Nitidulids as vectors of the oak wilt fungus and other Ceratocystis spp. in Texas. Eur J For Pathol 20:412-417. doi:10.1111/1439-0329.ep8118807.

Brasier CM (1991) Ophiostoma novo-ulmi sp. nov., causative agent of current Dutch elm disease pandemics. Mycopathologia 115:151-161. 
Chung W-H, Kim J-J, Yamaoka Y, Uzunovic A, Masuya H, Breuil C (2006) Ophiostoma breviusculum sp. nov. (Ophiostomatales, Ascomycota) is a new species in the Ophiostoma piceae complex associated with bark beetles infesting larch in Japan. Mycologia 98:801-814. doi:10.3852/mycologia.98.5.801.

Davidson RW (1935) Fungi causing stain in logs and lumber in the Southern States, including five new species. J Agric Res 50:789-807.

Davidson RW (1958) Additional species of Ophiostomataceae from Colorado. Mycologia 50:661670.

De Beer ZW, Harrington TC, Vismer HF, Wingfield BD, Wingfield MJ (2003) Phylogeny of the Ophiostoma stenoceras — Sporothrix schenckii complex. Mycologia 95:434-441.

De Hoog GS (1974) The genera Blastobotrys, Sporothrix, Calcarisporium and Calcarisporiella gen. nov. Stud Mycol 7:1-84.

DeVay JE, Davidson RW, Moller WJ (1968) New species of Ceratocystis associated with bark injuries on deciduous fruit trees. Mycologia 60:635-641.

Eckhardt LG, Weber AM, Menard R, Jones JP, Hess N (2007) Insect fungal complex associated with loblolly pine decline in Central Alabama. For Sci 53:84-92.

Gardes M, Bruns TD (1993) ITS primers with enhanced specificity for Basidiomycetesapplication to the identification of mycorrhizae and rusts. Mol Ecol 2:113-118. doi:10.1111/j.1365294X.1993.tb00005.x

Glass NL, Donaldson GC (1995) Development of primer sets designed for use with the PCR to amplify conserved genes from filamentous Ascomycetes. Appl Environ Microbiol 61:1323-1330.

Gorton C, Kim SH, Henricot B, Webber J, Breuil C (2004) Phylogenetic analysis of the bluestain fungus Ophiostoma minus based on partial ITS rDNA and $\beta$-tubulin gene sequences. Mycol Res 108:759-765. doi:10.1017/S0953756204000012.

Gregor MJF (1932) A study of heterothallism in Ceratostomella pluriannulata Hedgcock. Ann Mycol 30:1-9.

Griffin HD (1968) The genus Ceratocystis in Ontario. Can J Bot 46:689-718.

Grobbelaar J, Aghayeva D, De Beer ZW, Bloomer P, Wingfield M, Wingfield B (2009) Delimitation of Ophiostoma quercus and its synonyms using multiple gene phylogenies. Mycol Prog 8:221-236. doi:10.1007/s11557-009-0594-4.

Harrington TC, McNew D, Steimel J, Hofstra D, Farrell R (2001) Phylogeny and taxonomy of the Ophiostoma piceae complex and the Dutch Elm Disease fungi. Mycologia 93:111-136.

Hausner G, Eyjólfsdóttir GG, Reid J (2003) Three new species of Ophiostoma and notes on Cornuvesica falcata. Can J Bot 81:40-48.

Hedgcock GG (1906) Studies upon some chromogenic fungi which discolor wood. Mo Bot Gard Ann Rep 17:59-114. 
Kamgan NG, Jacobs K, De Beer ZW, Wingfield MJ, Roux J (2008) Ceratocystis and Ophiostoma species including three new taxa, associated with wounds on native South African trees. Fungal Divers 29:37-59.

Katoh K, Toh H (2008) Recent developments in the MAFFT multiple sequence alignment program. Brief Bioinform 9:286-298. doi:10.1093/bib/bbn013.

Livingston WH, Davidson RW (1987) Ophiostoma subannulatum, a new fungal species pathogenic to grand fir roots. Mycologia 79:144-147.

Malloch DW, Blackwell M (1993) Dispersal biology of the Ophiostomatoid fungi. In: Wingfield MJ, Seifert KA, Webber J (eds) Ceratocystis and Ophiostoma: taxonomy, ecology and pathogenicity. APS, St. Paul, Minn. pp 195-206.

Marmolejo JG, Butin H (1990) New conifer-inhabiting species of Ophiostoma and Ceratocystiopsis (Ascomycetes, Microascales) from Mexico. Sydowia 42:193-199.

Mathiesen-Käärik A (1953) Eine Übersicht über die gewöhnlichsten mit Borkenkäfern assoziierten Bläuepilze in Schweden und einige für Schweden neue Bläuepilze. Medd Statens Skogsforskninginst 43:1-74.

Menard R (2007) An assessment of the risk mapping system for the use of managing loblolly pine decline sites within redcockaded woodpecker habitat. MS Thesis, Louisiana State University.

Nylander JAA (2004) MrModeltest v2. Program distributed by the author. Evolutionary Biology Centre, Uppsala University.

O’Donnell K, Cigelnik E (1997) Two divergent intragenomic rDNA ITS2 types within a monophyletic lineage of the fungus Fusarium are nonorthologous. Mol Phylogenet Evol 7:103-116. doi:10.1006/mpev.1996.0376.

Otrosina W, Bannwart D, Roncadori R (1999) Root-infecting fungi associated with a decline of longleaf pine in the southeastern United States. Plant Soil 217:145-150.

doi:10.1023/A:1004645115446.

Posada D, Crandall KA (1998) MODELTEST: testing the model of DNA substitution. Bioinformatics 14:817-818. doi:10.1093/bioinformatics/14.9.817.

Romón P, Zhou X, Iturrondobeitia JC, Wingfield MJ, Goldarazena A (2007) Ophiostoma species (Ascomycetes: Ophiostomatales) associated with bark beetles (Coleoptera: Scolytinae) colonizing Pinus radiata in northern Spain. Can J Microbiol 53:756-767. doi:10.1139/W07-001.

Ronquist F, Huelsenbeck JP (2003) MrBayes 3: Bayesian phylogenetic inference under mixed models. Bioinformatics 19:1572-1574. doi:10.1093/bioinformatics/btg180.

Seifert KA (1993) Sapstain of commercial lumber by species of Ophiostoma and Ceratocystis. In: Wingfield MJ, Seifert KA, Webber J (eds) Ceratocystis and Ophiostoma: taxonomy, ecology and pathogenicity. APS, St. Paul, Minn., pp 141-151.

Tamura K, Dudley J, Nei M, Kumar S (2007) MEGA4: Molecular Evolutionary Genetics Analysis (MEGA) software version 4.0. Mol Biol Evol 24:1596-1599. doi:10.1093/molbev/msm092. 
Thwaites JM, Farrell RL, Duncan SM, Reay SD, Blanchette RA, Hadar E, Hadar Y, Harrington TC, McNew D (2005) Survey of potential sapstain fungi on Pinus radiata in New Zealand. N Z J Bot 43:653-663.

Upadhyay HP (1981) A monograph of Ceratocystis and Ceratocystiopsis. University of Georgia Press, Athens.

Verrall AF (1939) Relative importance and seasonal prevalence of wood-staining fungi in the Southern States. Phytopathology 29:1031-1051.

Verrall AF (1941) Dissemination of fungi that stain logs and lumber. J Agric Res 63:549-558.

Villarreal M, Rubio V, De Troya MT, Arenall F (2005) A new Ophiostoma species isolated from Pinus pinaster in the Iberian Peninsula. Mycotaxon 92:259-268.

White TJ, Bruns T, Lee S, Taylor J (1990) Amplification and direct sequencing of fungal ribosomal RNA genes for phylogenetics. In: Innis MA, Gelfand DH, Sninsky JJ, White TJ (eds) PCR protocols: a guide to methods and application. Academic, San Diego, pp 315-322.

Zhou XD, De Beer ZW, Wingfield BD, Wingfield MJ (2002) Infection sequence and pathogenicity of Ophiostoma ips, Leptographium serpens and L. lundbergii to pines in South Africa. Fungal Divers 10:229-240. 